\title{
$\left[{ }^{3} \mathrm{H}\right] 3-\mathrm{O}-\mathrm{Methyl}-\mathrm{D}$-glucose transport from blood into the lumina of the seminiferous and epididymal tubules in intact and vasectomized hamsters
}

\author{
T. T. Turner, D. A. D'Addario and S. S. Howards \\ Departments of Urology and Physiology, University of Virginia School of Medicine, \\ Charlottesville, Virginia 22908, U.S.A.
}

\begin{abstract}
Summary. The investigation demonstrated a restriction of $\left[{ }^{3} \mathrm{H}\right] 3-\mathrm{O}$-methyl-D-glucose $\left(\left[{ }^{3} \mathrm{H}\right] 3-\mathrm{OMG}\right)$ net transport into seminiferous tubule fluid. Net transport of $\left[{ }^{3} \mathrm{H}\right] 3-\mathrm{OMG}$ into the cauda epididymidal tubule was even more limited. By 4 months after vasectomy, there was no statistical difference in the net transport of the isotope into the seminiferous tubule fluid, but there was a significant increase in net transport into cauda epididymidal fluid. These results demonstrate that the blood-epididymal barrier can be even more restrictive to molecular transport than the blood-testis barrier and that vasectomy can have subtle effects on characteristics of molecular transport in the cauda epididymidis.
\end{abstract}

\section{Introduction}

Setchell, Voglmayr \& Waites (1969) demonstrated a blood-testis barrier which excluded blood-borne molecules from the rete testis fluid. Dym \& Fawcett (1970) described the anatomical basis of the blood-testis barrier as the Sertoli cell-Sertoli cell tight junctions surrounding the seminiferous tubules. Howards, Jessee \& Johnson (1976) directly characterized the ability of the blood-testis barrier to limit transport of blood-borne substances into the luminal fluids of the seminiferous tubule and also demonstrated that a similar, but not identical, barrier extended to the cauda epididymidis. The blood-testis and blood-epididymal barriers either partly or totally exclude molecules depending on the characteristics of the molecules. Of these characteristics, molecular size and lipid solubility (Setchell \& Main, 1978) are of considerable importance. Apart from the anatomically distinct tight-junctions described by Dym \& Fawcett (1970), physiological mechanisms are also important in determining the rate at which substances in blood appear in the seminiferous tubule. Turner, Hartmann \& Howards (1979b) presented evidence that $\left[{ }^{14} \mathrm{C}\right]$ urea was actively transported into the seminiferous tubule of the rat. Setchell, Laurie, Main \& Goats (1979) have recently reported that $\left[{ }^{3} \mathrm{H}\right]$ testosterone is transported into the rat seminiferous tubules by facilitated diffusion.

Whether or not vasectomy alters the physiology of the seminiferous tubule has been a question of considerable importance (see Lepow \& Crozier, 1979, for review). Turner \& Howards (1978) and Turner, D'Addario \& Howards (1979a) have reported subtle effects of vasectomy on both the blood-testis and blood-epididymal barriers. We have continued this line of investigation by studying the transport of $\left[{ }^{3} \mathrm{H}\right] 3-\mathrm{O}$-methyl-D-glucose $\left(\left[{ }^{3} \mathrm{H}\right] 3-\mathrm{OMG}\right)$, a non-metabolizable form of D-glucose with similar transport characteristics, into the testis and epididymis of intact and vasectomized hamsters. 


\section{Materials and Methods}

Mature, male, golden hamsters (100-150 g) were housed in a constant-temperature vivarium with a $14 \mathrm{~h}$ light $/ 24 \mathrm{~h}$ dark cycle. All animals were fasted for $24 \mathrm{~h}$ before experimental use.

\section{Intact animals}

Short-term exposure to $\left[{ }^{3} H\right] 3-O M G$. Animals were anaesthetized with an intraperitoneal injection of sodium-5-ethyl-5-(1-methyl propyl)-2-thiobarbiturate (Inactin: Byk Guilden Konstanz, Hamburg, Germany) in a dose of $200 \mathrm{mg} / \mathrm{kg}$ body weight. A jugular venous cannula was inserted to allow infusion of fluids. A carotid arterial cannula was inserted to allow sampling of arterial blood. The testes and epididymides were exposed through a scrotal incision and prepared for micropuncture as described by Howards, Johnson \& Jessee (1975).

The animals were infused with a 'priming dose' of $350 \mu \mathrm{Ci}\left[{ }^{3} \mathrm{H}\right]-3-\mathrm{OMG}$ (sp. act. $60-90$ $\mathrm{Ci} / \mathrm{mmol}$; New England Nuclear, Boston, Massachusetts). This dose was administered via the venous cannula in $0.5 \mathrm{ml} 0.154 \mathrm{M}-\mathrm{MaCl}$ over $1.5 \mathrm{~min}$. A 'sustaining dose' of isotope was administered over a $4-\mathrm{h}$ period by slow continuous infusion of $350 \mu \mathrm{Ci}\left[{ }^{3} \mathrm{H}\right] 3-\mathrm{OMG}$ in $3.0 \mathrm{ml}$ $0.154 \mathrm{M}-\mathrm{NaCl}$. Micropuncture samples of fluid from the seminiferous tubules and cauda epidymidis were collected $30 \mathrm{~min}$ after the start of the sustaining dose infusion and continued thereafter at 30-min intervals for $4 \mathrm{~h}$. Arterial blood samples were collected via the carotid cannula according to the same time schedule. Cell-free seminiferous tubule fluid, fluid from the cauda epididymidis, and blood plasma were obtained by centrifuging microsamples in a refrigerated centrifuge at $35000 \mathrm{~g}, 0^{\circ} \mathrm{C}$, for $15 \mathrm{~min}$.

By use of a microsample transferring apparatus (Bunton Instruments Co., Rockville, Maryland), $100 \mathrm{nl}$ cell-free fluids were transferred under oil into a calibrated volumetric micropipette. These aliquots were then placed in $10 \mathrm{ml}$ scintillation fluid and analysed for radioactivity in a scintillation spectrophotometer (Packard Tricarb, model 3375). All samples were prepared and analysed in duplicate.

Long-term exposure to $\left[{ }^{3} \mathrm{H}\right] 3-O M G$. Normal hamsters were anaesthetized with sodium pentabarbitone $(40 \mathrm{mg} / \mathrm{kg}$ body weight). The animals were bilaterally nephrectomized to prevent renal excretion of isotope and $700 \mu \mathrm{Ci}$ of $\left[{ }^{3} \mathrm{H}\right] 3-\mathrm{OMG}$ in $1 \mathrm{ml} 0.154 \mathrm{M}-\mathrm{NaCl}$ were infused via the femoral vein. The animals were allowed to recover, but were re-anaesthetized with Inactin $9.5 \mathrm{~h}$ later. Micropuncture samples of seminiferous tubule fluid and cauda epididymidal fluid were taken $10 \mathrm{~h}$ after isotope infusion. Blood was collected via a carotid cannula. Quadruplicate samples of each fluid were obtained. Triplicate aliquots of each sample were transferred into scintillation vials and analysed for radioactivity as described previously. While attempts were made to collect microsamples from animals at $20 \mathrm{~h}$ after infusion of the isotope, these nephrectomized animals did not tolerate re-anaesthesia well and successful micropuncture was not possible.

\section{Vasectomized animals}

Hamsters were anaesthetized with Inactin and bilaterally vasectomized through a laparotomy incision. Care was taken not to involve the vasal artery and vein while ligating and transecting the vas deferens. After surgery, all animals were palpated to ensure scrotal location of the testis and epididymides. At 4 months after vasectomy, the hamsters were subjected to the same preparation, isotope infusion and $4 \mathrm{~h}$ micropuncture collection as described above for the short-term exposure of control animals to $\left[{ }^{3} \mathrm{H}\right] 3-\mathrm{QMG}_{\text {eled }}$ from Bioscientifica.com at 04/26/2023 09:58:40AM 


\section{Data analysis}

Counts per minute (c.p.m.) per unit volume of tubule fluid were divided by c.p.m. per unit volume of blood plasma collected at the same time period. This quotient, multiplied by 100 , reflected that percentage of isotope in the plasma which was able to enter the tubule fluids at each time period. Analysis of covariance was used to determine if significant differences existed between the entry of $\left[{ }^{3} \mathrm{H}\right] 3-\mathrm{OMG}$ into the tubule fluids of normal and vasectomized hamsters.

\section{Results}

The results for the intact animals are shown in Text-fig. 1(a). Considering all time periods, the percentages of plasma isotope concentrations detected in the seminiferous tubule fluid were significantly greater $(P<0.001)$ than those in the fluid from the cauda epididymidis. The mean value between 120 and $240 \mathrm{~min}$ of the infusion period was $41.9 \pm 3.4 \%$ (s.e.m.) for the seminiferous tubule fluid and $6.6 \pm 1.0 \%$ for the epididymal fluid. The $10 \mathrm{~h}$ values were similar.

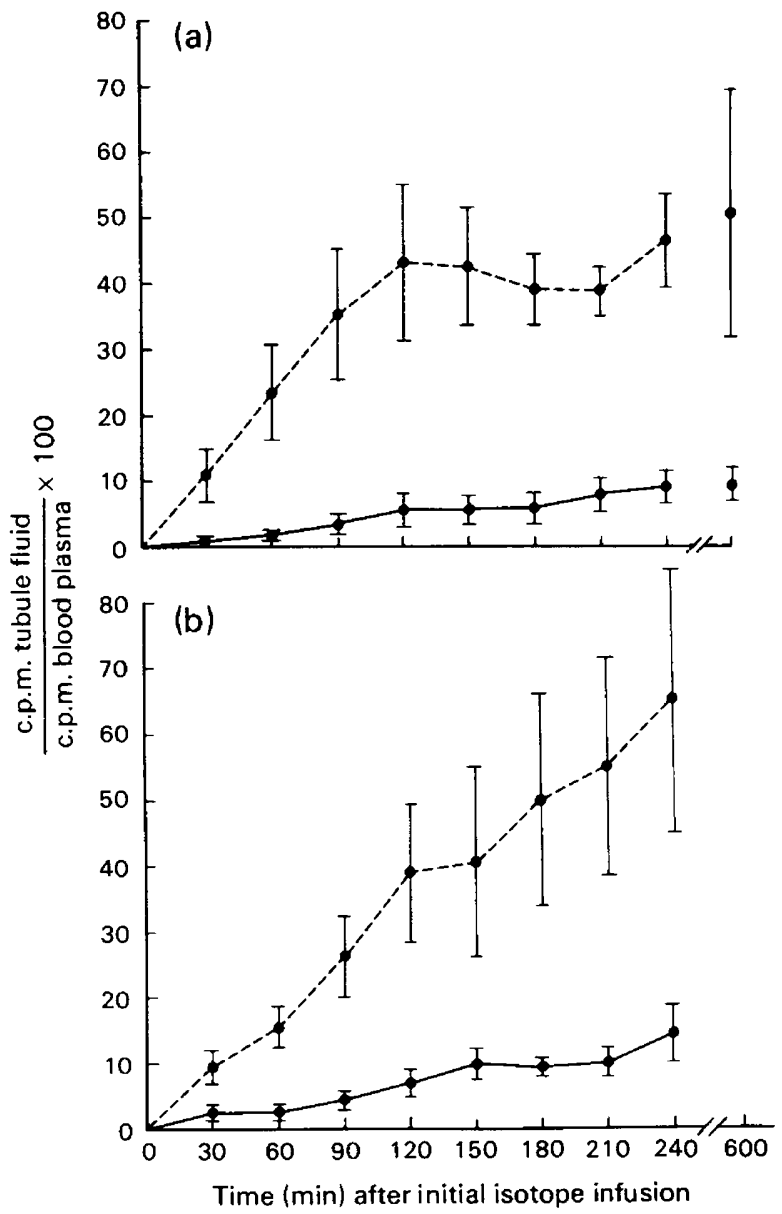

Text-fig. 1. Entry of $\left[{ }^{3} \mathrm{H}\right] 3-\mathrm{O}$-methyl-D-glucose into the luminal fluids of the hamster seminiferous tubule (--) and the cauda epididymidis (-) of (a) intact hamsters and (b) hamsters vasectomized for 4 months. Values are mean \pm s.e.m. percentages of blood plasma isotope concentrations appearing in reproductive tract fluids of 4 animals in each group. 
Similar results were obtained from the vasectomized hamsters (Text-fig. 1b). Analysis of covariance showed that a significantly greater $(P<0.01)$ percentage of blood isotope concentrations appeared in seminiferous tubule fluid than in the epididymal fluid. The mean \pm s.e.m. values between 120 and $240 \mathrm{~min}$ were $49 \cdot 2 \pm 6.5 \%$ for seminiferous tubule fluid and $10 \cdot 1 \pm 1.1 \%$ for the fluid from the cauda epididymidis. Data from the seminiferous tubule fluid of intact and vasectomized hamsters were not significantly different; however, values for fluid from the cauda epididymidis of vasectomized animals were significantly higher $(P<0.01)$ than values from intact hamsters.

\section{Discussion}

Glucose, an important energy substrate readily available to most tissues and cells, is present in very low concentrations or completely absent in rete testis fluid and the fluid from the cauda epididymidis of several species (Voglmayr, Waites \& Setchell, 1966; Wales, Wallace \& White, 1966; Jones \& Glover, 1973). It is not known whether these low concentrations are due to a barrier to entry or to cellular utilization of glucose inside the tubule lumina. The present results demonstrate that $\left[{ }^{3} \mathrm{H}\right] 3-\mathrm{OMG}$ concentrations in the luminal fluid of the hamster seminiferous tubule and cauda epididymidis are not as high as those in blood plasma. This indicates that, in the hamster, low intratubular glucose concentrations can be at least partly attributed to a lack of net glucose transport from blood into the lumen of the seminiferous and epididymal tubule. The plateau values obtained at $40-50 \%$ and $5-10 \%$ of blood plasma values for the seminiferous and epididymal tubules, respectively, imply that a steady-state of $\left[{ }^{3} \mathrm{H}\right] 3-\mathrm{OMG}$ exchange was reached and that the duration of sampling was sufficient to detect maximum net transport.

The blood-cauda epididymidal barrier allows less net transport of $\left[{ }^{3} \mathrm{H}\right] 3-\mathrm{OMG}$ than the blood-testis barrier surrounding the seminiferous tubule. The inability of $\left[{ }^{3} \mathrm{H} \mid 3-\mathrm{OMG}\right.$ to cross easily into the lumen of the cauda epididymidis in this study is similar to results of Cooper \& Waites (1979) whose luminal perfusion studies showed that there was only minimal entry $\left[{ }^{14} \mathrm{C}\right.$ lglucose and $\left[{ }^{3} \mathrm{H}\right] 3-\mathrm{OMG}$ into the lumen of the rat epididymis. These results and those of Turner et al. (1979a) with $\left[{ }^{3} \mathrm{H}\right.$ ]inulin confirm that the blood-epididymal barrier can be a greater barrier to net molecular transport than the more often studied blood-testis barrier.

These transport barriers are not necessarily simply structural entities like those demonstrated in the morphological studies of Dym \& Fawcett (1970). The effects of an anatomical barrier may be modified by membrane transport systems on the basal and/or luminal surface of the Sertoli or epididymal epithelial cell. Molecular movement across these membranes could be either by passive, facilitated, pro-luminal active, or anti-luminal active transport. Brooks (1979), for example, has presented evidence that movement of glucose into epididymal epithelial cells in vitro is by facilitated transport. The present results could also be explained by free movement of $\left[{ }^{3} \mathrm{H}\right] 3-\mathrm{OMG}$ into the tubules followed by antiluminal active transport of $\left[{ }^{3} \mathrm{H}\right] 3-\mathrm{OMG}$ on the luminal surface of the Sertoli and epididymal epithelial cells. The difference in percentage of blood isotope appearing in the seminiferous and cauda epididymidal fluids could then be explained by a different rate of anti-luminal pumping on the membrane of the two different cell types involved. The tubule fluid to blood ratio of glucose is probably different from the ratio of $\left[{ }^{3} \mathrm{H} \mid 3-\mathrm{OMG}\right.$ observed in these studies because the common carrier may have different affinities for the two carbohydrates.

The only obvious effect of vasectomy on the ability of [ ${ }^{3} \mathrm{H}$ 13-OMG to enter the seminiferous tubule fluid was the increased variance; however, vasectomized hamsters contained significantly more $\left[{ }^{3} \mathrm{H}\right] 3-\mathrm{OMG}$ in the epididymal fluid than did intact hamsters. This difference could be due to a disturbance of a structural barrier or to a decrease in the activity of an outward directed glucose pump.

An alteration in cauda epididymidal tubule permeability is not surprising in view of the fact 
that vasectomy probably stresses this region of the male reproductive tract more severely than any other. These results corroborate those of Turner et al. (1979a) that vasectomy causes subtle alterations in the physiology of the cauda epididymidal tubule.

\section{References}

Brooks, D.E. (1979) Carbohydrate metabolism in the rat epididymis: evidence that glucose is taken up by tissue slices and isolated cells by a process of facilitated transport. Biol. Reprod. 21, 19-26.

Cooper, T.C. \&Waites, G.M.H. (1979) Investigations by luminal perfusion of the transfer of compounds into the epididymis of the anaesthetized rat. J. Reprod. Fert. 56, 159-164.

Dym, M. \& Fawcett, D.W. (1970) Observations on the blood-testis barrier of the rat on the physiological compartmentation of the seminiferous epithelium. Biol. Reprod. 3, 308-326.

Howards, S.S., Johnson, A.L. \& Jessee, S.J. (1975) Micropuncture and microanalytic studies of the rat testis and epididymis. Fert. Steril. 26, 13-19.

Howards, S.S. Jessee, S.J. \& Johnson, A.L. (1976) Micropuncture studies of the blood-seminiferous tubule barrier. Biol. Reprod. 14, 264-269.

Jones. R. \& Glover, T.D. (1973) The collection and composition of epididymal plasma from the cauda epididymidis of the rabbit. J. Reprod. Fert. 34, 395-403.

Lepow, I.C. \& Crozier, R. (1979) Vasectomy: Immunologic and Pathophysiologic Effects in Animals and Man. Academic Press, New York.

Setchell, B.P. \& Main, S.J. (1978) Drugs and the blood-testis barrier. Environ. Health Persp. 24, 61-64.

Setchell, B.P., VogImayr, J.K. \& Waites, G.M.H. (1969)

A blood-testis barrier restricting passage from blood into rete testis fluid but not into lymph. J. Physiol., Lond. 200, 73-85.

Setchell, B.P., Laurie, M.S., Main, S.J. \& Goats, G.C. (1979) The mechanism of transport of testosterone through the walls of the seminiferous tubules of the rat testis. Int. J. Androl., Suppl. 2, 506-512.

Turner, T.T. \& Howards, S.S. (1978) The effects of vasectomy on the movement of ${ }^{14} \mathrm{C}$-urea in the seminiferous tubule of the hamster. Invest. Urol. 16, 237-239.

Turner, T.T., D'Addario, D.A. \& Howards, S.S. (1979a) Effects of vasectomy on the blood-testis barrier of the hamster. J. Reprod. Fert. 55, 323-328.

Turner, T.T., Hartmann, P.K. \& Howards, S.S. (1979b) Urea in the seminiferous tubule: evidence for active transport. Biol. Reprod. 20, 511-515.

Voglmayr, J.K., Waites, G.M.H. \& Setchell, B.P. (1966) Studies on spermatozoa and fluid collected directly from the testis of the conscious ram. Nature, Lond. 210, 861-863.

Wales, R.G., Wallace, J.C. \& White, I.G. (1966) Composition of bull epididymal and testicular fluid. J. Reprod. Fert. 12, 139-144.

Received 24 December 1979 